\title{
Effects of Industrial Effluents Polluting the Ismailia Water Canal on Growth and Metabolic Responses of Pisum sativum Seedlings
}

\author{
Abdel Haleem Mohammed Ahmed and Rania Samy Hanafy* \\ Department of Biological \& Geological Sciences, Faculty of Education, Ain Shams \\ University, Cairo, Egypt.
}

\begin{abstract}
$\mathbf{T}$ HE AIM of this work was to evaluate the impact of sources of waste water pollution on Ismailia canal and irrigated plants. The industrial sources along Ismailia canal produce large wastes that disturb the environmental balance. This study was based on investigating the growth and biochemical characteristics of Pisum sativum seedlings irrigated with industrial waste water collected from three selected stations of Ismailia canal. Results revealed an enrichment of organic matter and heavy metals in polluted water. Irrigation of plants using waste water affected germination, physiological, biochemical and growth characteristics of Pisum sativum. Irrigation with polluted water reduced photosynthetic pigments, total nitrogen and proteins in plant. Uptake and translocation of heavy metals and metal ions were higher in the polluted Pisum sativum which produced more metabolites to combat metal toxicity. High activity of antioxidant enzymes (Catalase, peroxidase and polyphenol oxidase), the contents of soluble sugars, anthocyanine, proline and new protein bands were induced.
\end{abstract}

Keywords: Anthocyanin, Antioxidant, Carbohydrates, Heavy metal, Proline, Waste water.

\section{Introduction}

Ismailia canal is one of the most important sources for potable and irrigation waters in Egypt. It was found that some industrial regions located along this canal (that include the activities of petroleum, petro gas, iron and steel, Abu Za'baal Fertilizers Company, Alum (Aluminum Sulfate) Company, detergent industries and electric power station that discharge their wastes into the water of the canal cause changes in the physical and chemical characteristics of water (El-Sayed, 2008). These wastes lead to the accumulation of toxic heavy metals in water. Water polluted with heavy metals is most serious environmental problems because of their resistance and toxic effects (Khalil et al., 2007). The excessive amount of heavy metals in agricultural soils coming from wastewater irrigation result in substantial amounts of potentially toxic metals into the food chain and thus cause toxic effects on human, animals and plants (Majid et al., 2012). High levels of heavy metals affect both growth and physiological metabolism of plants, waste water damages to plants are produced by a combination of several causes, including osmotic injury (Briccoli et al., 1994) and specific ion toxicity (Zeid \& Abou ElGhate, 2007). Plants can adapt to waste water depending on the increase of salt avoidance through the induction of specific organic solutes (such as proline) that help in osmoregulation through preventing salt and trace elements to accumulate in cells (Toze, 2006). On the other hand, accumulations of toxic heavy metals stimulate the stress conditions and interfere with physiological and metabolic activities in plants (Long et al., 2003 ) by causing the formation of reactive oxygen species (ROS)(superoxide radicals $\left(\mathrm{O}_{2}\right)$, hydroxyl radical $(\mathrm{OH})$ and hydrogen peroxide) (Verma \& Dubey, 2001).Plants survive the stress condition by inducing the accumulation of enzymatic and non- enzymatic antioxidants for scavenging these free radicals (Gratäo et al., 2005).

The present study was conducted to compare the effect of irrigation with industrial waste water on Pisum sativum var Master B. seedlings in term of growth, physiological and biochemical parameters.

\section{Materials and Methods}

Collection and analysis of water samples

Three stations along Ismailia Canal were chosen for the study, the mouth of Ismailia canal branched from River Nile at El-Mazalat square

\footnotetext{
*Corresponding auhtor email: raniaamin91@yahoo.com, Tel.: 01007779364

*DOI :10.21608/ejbo.2017.1185.1106

(C)2017 National Information and Documentation Center (NIDOC)
} 
(The mouth of canal, $30^{\circ} 630^{\natural} \mathrm{N}, 31^{\circ} 15^{\backslash} 10^{\prime} \mathrm{E}$ ) (as a control), Mostourd ( $\left.30^{\circ} 09^{\backslash} 55^{\Downarrow \prime} \mathrm{N} 31^{\circ} 17^{\backslash 36} 36^{\prime} \mathrm{E}\right)$ and $\mathrm{Abu} \mathrm{Za}^{\prime}$ baal $\left(30^{\circ} 16 \backslash 46^{\prime \prime} \mathrm{N}, 31^{\circ} 2306^{\prime \prime} \mathrm{E}\right)$ (Fig. $1)$. Water samples were collected from these three stations at $60 \mathrm{~cm}$ depth (sub surface layer) and kept in plastic bottle then returned immediately to the laboratory for analysis.Organic matter and total heavy metal contents $(\mathrm{Zn}, \mathrm{Cd}, \mathrm{Ni}$ and $\mathrm{Cu}$ ) in all water samples after digestion by concentrated $\mathrm{HNO}_{3}$ were measured according to APHA et al. (2005) using atomic absorption spectrophotometer.

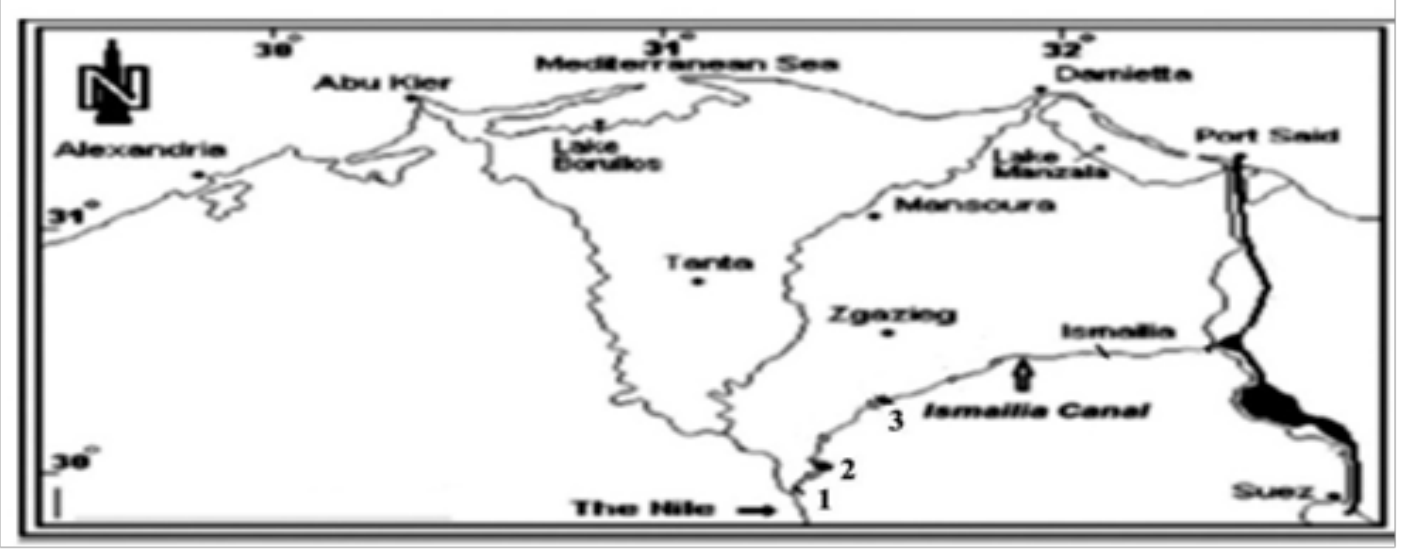

Fig.1. Studied locations at Ismailia Canal in Egypt.(1: El-Mazalat, 2:Mostourd, 3: Abu Za'baal.

\section{Plant materials}

Seeds of Pisum sativum var Master B were obtained from Agricultural Research Centre, Giza, Egypt. The experiments were located inside an open wire house exposed to normal day length and illumination (16/8 h. light/dark) in Faculty of Education, Ain Shams University. Homogeneous Pisum sativum seeds were surface sterilized by $0.01 \mathrm{M} \mathrm{HgCl}_{2}$ solution for $3 \mathrm{~min}$ and washed thoroughly with distilled water. The plastic pots $(14 \times 17 \mathrm{~cm})$ were filled with equal amount $(0.5 \mathrm{~kg})$ of clay soil. They were divided into four groups; each group consisted of 10 pots. The $1^{\text {st }}$ group was irrigated with water collected from the first region (El-Mazalat) and used as control; the $2^{\text {nd }}$ and $3^{\text {rd }}$ groups were irrigated with polluted water collected from selected sites at Mostourd and Abu Za'baal, respectively. After 7 days from sowing, thinning was done to leave 8 uniform seedlings in each pot to complete the experiment.Growth and biochemical responses were observed at 15 and 30 days of growth after sowing. Ten replicates were collected randomly from pots of control and the pots irrigated with waste water for studying the growth parameters. Shoot and root lengths, number of leaves and roots, assimilating area of leaves, fresh and dry weights of shoots and roots were quantified. Triplicates were collected for measuring the pigments, total nitrogen, total protein, total soluble sugars, total carbohydrates, anthocyanin, proline content and enzyme activities (catalase, peroxidase and polyphenol oxidase). Heavy metals $(\mathrm{Zn}, \mathrm{Cd}, \mathrm{Ni}$ and $\mathrm{Cu})$ were analyzed in both water and plant samples, mineral ions $(\mathrm{Mg}$, $\mathrm{Fe}, \mathrm{Na}, \mathrm{K}$ ) and protein banding patterns was also determined and analyzed in the plants.

\section{Determination of seed germination}

The seeds were arranged in $15 \mathrm{~cm}$ Petri dishes covered with two sheets of filter paper moistened with $10 \mathrm{ml}$ of waste water collected from the chosen regions. Seed germination (\%) was observed by providing optimum conditions for experiment. The germination percentage was recorded according to ISTA (1993).

\section{Metabolic analysis}

Determination of photosynthetic pigments

Chlorophyll a, chlorophyll b and carotenoids contents were extracted according to the method of Metzner et al. (1965). The absorbance was determined in the supernatant colorimetrically and according to Lichtenthaler \& Wellburn (1983) formulae pigment concentration was calculated and expressed as $\mathrm{mg} \mathrm{g}^{-1} \mathrm{FW}$.

$$
\begin{aligned}
& \text { Assay of Total nitrogen and total protein } \\
& \text { content } \\
& \text { Total nitrogen was determined in dry tissues } \\
& \text { by the method of Yemm \& Willis (1956) using } \\
& \text { micro- Kjeldal method. Estimation of total protein } \\
& \text { was done according to the method of Lowry et al. }
\end{aligned}
$$


(1951). The protein concentration was determined using bovine serum albumin as standard. Absorbance was recorded photometrically at 595 nm.

Determination of total soluble sugars (TSS) and total carbohydrate contents

Total soluble sugars were estimated by the method of Dubois et al. (1956). Total carbohydrate content was measured by the method of Asgharipour et al. (2011) using glucose as standard. Contents of carbohydrate were expressed as $\mathrm{mg} \mathrm{g}^{-1} \mathrm{DW}$.

Determination of anthocyanin content

Anthocyanin content was estimated according to the method adopted by Krizek et al. (1993). The absorbance was measured at $550 \mathrm{~nm}$ and it was expressed as $\mu \mathrm{M} \mathrm{g}^{-1} \mathrm{FW}$.

\section{Determination of proline content}

Proline content was colorimetrically estimated in fresh leaf samples according to Bates et al. (1973), and the absorbance was determined at $520 \mathrm{~nm}$.

Determination of antioxidant enzyme activities

For the assay of antioxidant enzymes, catalase (EC 1.11.1.6), peroxidase (EC 1.11.1.7) and polyphenol oxidase (EC 1.14.18.1), the activity of catalase was measured colorimetrically according to the method of Aebi (1984). The absorbance was measured at $240 \mathrm{~nm}$. Catalase activity was expressed as $\mathrm{H}_{2} \mathrm{O}_{2}$ destroyed $\mathrm{g}^{-1} \mathrm{FW} \mathrm{h}^{-1}$. Peroxidase and polyphenol oxidase were extracted following the method of Kar \& Mishra (1976). The color intensity was read at $430 \mathrm{~nm}$ and the enzyme activities were expressed as the change in the optical density $\mathrm{g}^{-1} \mathrm{FW} \mathrm{h}^{-1}$.

Determination of heavy metal content in plants

Heavy metals ( $\mathrm{Zn}, \mathrm{Cd}, \mathrm{Ni}, \mathrm{Cu}$ ) analysis of plant samples were carried out according to Allen et al. (1986) and their concentrations was determined using atomic absorption spectrophotometer.

\section{Determination of mineral ion contents}

The mineral ion contents of $\mathrm{Mg}^{+2}, \mathrm{Fe}^{+2}$, $\mathrm{K}^{+}$and $\mathrm{Na}^{+}$were determined according to Chapman \& Pratt (1978) method. Flame emission spectrophotometry was used for determining of $\mathrm{K}^{+}$and $\mathrm{Na}^{+}$while $\mathrm{Mg}^{+2}$, and $\mathrm{Fe}^{+2}$ were measured using atomic absorption spectrophotometer.

\section{Polyacrylamide gel electrophoresis (SDS- PAGE)}

The determination and identification of different protein fractions from treated and control Pisum sativum seedlings were obtained using continuous polyacrylamide gel electrophoresis in the presence of sodiumdodecyl sulphate (Cont, SDS-PAGE) as described by Laemmli (1970). For gel analysis, gel was photographed scanned and analyzed using a Laser Gel Documentation System (GDS).

\section{Statistical analysis}

Data of all parameters were statistically analyzed by using ANOVA test and the mean differences were compared using the Duncan test at $5 \%$ significance level.

\section{Results and Discussion}

Results obtained by visual observations made in the laboratory are presented in Table 1 which highlights the influence of quality of water on the germination percentage of Pisum sativum. Seed germination and seedling growth are very responsive to the environmental changes. A significant decrease in seed germination was recorded for the seeds irrigated with waste water collected from Mostourd region, and in case of $\mathrm{Abu} \mathrm{Za}^{\prime}$ baal, the decrease was non-significant as compared with that of the control.These findings are in line with Pantea et al. (2012) who found that the seed germination rate of tomato (Lycopersicon esculentum) was decreased with increasing concentration of waste water and this may be because of the reduction in nutrient in the activated sludge basins. Daud et al., (2016) also found a reduction in seed germination of maize at different concentrations of collected waste water. This effect might could be due to the increase in the osmotic potential of the effluents at greater concentration of total salts, making imbibition more difficult and ultimately retard germination efficiencies. The waste water samples collected from the chosen regions showed high concentrations of heavy metals ( $\mathrm{Zn}, \mathrm{Cd}, \mathrm{Ni}$ and $\mathrm{Cu}$ ). Such high levels of heavy metals might cause enhancement of salinity in water as reported by Pandey \& Srivastava (2002). These results agreed with that of Naaz \& Pandey (2010), El-Sharabasy \& Ibrahim (2010) who showed high levels of 
heavy metal in water samples collected from sites chosen along the Ismailia canal. These variations in the content of heavy metals along Ismailia canal may be due to a variety of industries on the two canal banks that discharge water into the canal, thus the high levels of heavy metals when transfer to the irrigation system or agricultural fields pose a risk to food production (Pandey, 2008). Throughout the experimental period it is clearly shown that, the irrigation of plants with water collected from Mostourd and Abu Za'baal regions, caused a significant reduction in all vegetative growth parameters at 15 and 30 days of growth as compared with control (Table 2). These results are in accord with those obtained by Hassanein et al. (2013) who demonstrated that irrigation with industrial waste water collected from the El-Amia drain in Egypt between Kafr-El Dawar south and AboQir north showed significant reduction in the growth of lettuce (Lactuca sativa L.) and turnip (Brassica napus L.) (Leaf area, shoot and root fresh and dry weights). In addition Daud et al. (2016) revealed a decrease in plant length of maize seedlings with the increase in concentrations of different sewage waters. Wastewater negatively affects plants growth due to a combination of several causes, including osmotic injury (Briccoli et al., 1994) and heavy metal toxicity (Zeid \& Abou-El Ghate, 2007).

TABLE 1. Effect of irrigation with waste water on \% seeds germination. The content of heavy metals in collected waste water. 1): Uncontaminated water as control (El-Mazalat station), 2): Industrial wastewater (Mostourd station) and 3): Industrial wastewater (Abu- Za'baal station).

\begin{tabular}{lccccc}
\hline \multirow{2}{*}{ Sample Zone } & \% germination & \multicolumn{4}{c}{ Heavy metals in water $\left(\boldsymbol{\mu g ~ \mathbf { ~ m } ^ { - 1 }}\right)$} \\
\cline { 3 - 5 } & & $\mathbf{Z n}^{+2}$ & $\mathbf{C d}^{+2}$ & $\mathbf{N i}^{+2}$ & $\mathbf{C u}^{+2}$ \\
\hline 1 & $94^{\mathrm{a}}$ & $0.031^{\mathrm{b}}$ & $0.015^{\mathrm{a}}$ & $0.012^{\mathrm{b}}$ & $0.01^{\mathrm{b}}$ \\
2 & $81^{\mathrm{b}}$ & $0.060^{\mathrm{a}}$ & $0.026^{\mathrm{a}}$ & $0.027^{\mathrm{a}}$ & $0.042^{\mathrm{a}}$ \\
3 & $90^{\mathrm{a}}$ & $0.053^{\mathrm{a}}$ & $0.017^{\mathrm{a}}$ & $0.021^{\mathrm{ab}}$ & $0.035^{\mathrm{a}}$ \\
\hline
\end{tabular}

Mean values $(n=5)$ in each column followed by the same letters are not significantly different at $\mathrm{P} \leq 0.05$ by Duncan's multiple range test.

TABLE 2. Effect of irrigation with waste water on different growth parameters of Pisum sativum seedling irrigated with waste water. 1): Uncontaminated water as control (El-Mazalat station), 2): Industrial wastewater (Mostourd station) and 3): Industrial wastewater (Abu- Za'baal station).

\begin{tabular}{|c|c|c|c|c|c|c|c|c|c|}
\hline Stage & $\begin{array}{c}\text { Sample } \\
\text { Zone }\end{array}$ & $\begin{array}{c}\text { Shoot } \\
\text { Length } \\
\text { (cm) }\end{array}$ & $\begin{array}{c}\text { Root } \\
\text { Length } \\
\text { (cm) }\end{array}$ & $\begin{array}{l}\text { No. of } \\
\text { leaves }\end{array}$ & $\begin{array}{l}\text { Leaf } \\
\text { area } \\
\left(\mathrm{cm}^{2}\right)\end{array}$ & $\begin{array}{c}\text { Shoot } \\
\text { fresh wt. } \\
\text { (g) }\end{array}$ & $\begin{array}{l}\text { Shoot } \\
\text { dry wt. } \\
\text { (g) }\end{array}$ & $\begin{array}{c}\text { Root } \\
\text { fresh wt. } \\
\text { (g) }\end{array}$ & $\begin{array}{c}\text { Root } \\
\text { dry wt. } \\
\text { (g) }\end{array}$ \\
\hline \multirow{3}{*}{$\begin{array}{l}15 \\
\text { days }\end{array}$} & 1 & $7.8^{c}$ & $10.4^{\mathrm{bc}}$ & $3.2^{\mathrm{b}}$ & $8.2^{\mathrm{c}}$ & $0.412^{\mathrm{c}}$ & $0.028^{\mathrm{b}}$ & $0.176^{\mathrm{b}}$ & $0.016^{\mathrm{cd}}$ \\
\hline & 2 & $5.1^{\mathrm{c}}$ & $5.4^{\mathrm{d}}$ & $2.2^{b}$ & $3.89^{\mathrm{d}}$ & $0.248^{\mathrm{c}}$ & $0.022^{b}$ & $0.146^{b}$ & $0.012^{\mathrm{d}}$ \\
\hline & 3 & $7.5^{c}$ & $7.7^{\mathrm{cd}}$ & $3.0^{\mathrm{b}}$ & $6.23^{\mathrm{cd}}$ & $0.362^{\mathrm{c}}$ & $0.024^{b}$ & $0.158^{b}$ & $0.014^{\mathrm{cd}}$ \\
\hline \multirow{3}{*}{$\begin{array}{l}30 \\
\text { days }\end{array}$} & 1 & $22^{a}$ & $20^{\mathrm{a}}$ & $6.5^{\mathrm{a}}$ & $29.58^{a}$ & $0.85^{\mathrm{a}}$ & $0.062^{\mathrm{a}}$ & $0.55^{\mathrm{a}}$ & $0.024^{\mathrm{a}}$ \\
\hline & 2 & $15.5^{b}$ & $12.5^{b}$ & $4.0^{\mathrm{ab}}$ & $22.04^{b}$ & $0.63^{b}$ & $0.043^{\mathrm{ab}}$ & $0.37^{\mathrm{ab}}$ & $0.020^{\mathrm{abc}}$ \\
\hline & 3 & $18.5^{\mathrm{ab}}$ & $14.4^{b}$ & $5.1^{\mathrm{ab}}$ & $27.10^{\mathrm{a}}$ & $0.70^{a b}$ & $0.050^{\mathrm{a}}$ & $0.48^{\mathrm{a}}$ & $0.022^{\mathrm{ab}}$ \\
\hline
\end{tabular}

Mean values $(\mathrm{n}=5)$ in each column followed by the same letters are not significantly different at $\mathrm{P} \leq 0.05$ by Duncan's multiple range test. 
Bini et al. (2012) reported that the deleterious effects of wastewater (polluted with heavy metals) on shoot and root fresh weights may be related to the effect of these metals in the reduction of water uptake and inhibition nutrients uptake consequently inhibiting normal plant growth. On the other hand plant adapted to waste water stress conditions by the increase in specific organic solutes (mainly proline) that was found to reduce free radical species level (Hong et al., 2000) and help in osmo-regulation within the cells (Al-Absi, 2008). These results of the presence of toxic substances in the waste water may be resulted in a bad damage of the chloroplast machinery of the plant leaves. These observations are further confirmed by an overall decline in the photosynthetic pigments. The pigment contents (chlorophyll a, b and total pigments) were found to be significantly decreased but the carotenoids were increased in leaves of plants irrigated with wastewater as compared with control after15 and 30 days of germination (Table 3 ). These results could be reinforced by the finding of Noori
\& Norzi (2014) in Aegilops columnaris plants and Daud et al. (2016) in maize seedlings. The induced level in carotenoids acts as nonenzymatic antioxidant that protects plants from oxidative stress by changing the properties of photosynthetic membranes with involvement of xanthophylls cycle (Gruszecki \& Strzatka, 1991). In response to the irrigating of Pisum plants with collected wastewater showed a significant decrease in total- $\mathrm{N}$ and total protein contents during the experimental periods (Table 4). These results reinforced by the results of Shukry (2001a) who reported that the protein-N and total nitrogen were decreased in Triticum sativum and Vicia faba plants irrigated with industrial polluting water of River Nile. Bamniya et al. (2010) recorded that the total nitrogen and total protein decline in Brassica oleracea and Spinacia oleracea crops irrigated with wastewater. Also, several studies have been found that stress may be induced the reduction in protein contents in waste water stressed plants (Hsu \& Kao, 2003 and Rong Guo et al., 2007).

TABLE 3. Effect of irrigation with wastewater on chlorophyll a, chlorophyll $b$, carotenoids and total pigments of Pisum sativum seedling. 1): Uncontaminated water as control (El-Mazalat station), 2): Industrial wastewater (Mostourd station) and 3): Industrial wastewater (Abu- Za'baal station).

\begin{tabular}{|c|c|c|c|c|c|}
\hline \multirow{2}{*}{ Stage } & \multirow{2}{*}{ Sample Zone } & \multicolumn{4}{|c|}{ Photosynthetic pigments $\left(\mathrm{mg} \mathrm{g}^{-1} \mathrm{FW}\right)$} \\
\hline & & Chlorophyll a & Chlorophyll b & Carotenoids & $\begin{array}{c}\text { Total } \\
\text { pigments }\end{array}$ \\
\hline \multirow{3}{*}{15 days } & 1 & $10.24^{\mathrm{a}}$ & $3.48^{\mathrm{a}}$ & $2.32^{\mathrm{c}}$ & $16.04^{\mathrm{a}}$ \\
\hline & 2 & $8.77^{\mathrm{abc}}$ & $1.13^{\mathrm{c}}$ & $4.96^{\mathrm{a}}$ & $14.86^{\mathrm{c}}$ \\
\hline & 3 & $9.51^{\mathrm{ab}}$ & $2.11^{\mathrm{b}}$ & $3.66^{\mathrm{b}}$ & $15.28^{\mathrm{b}}$ \\
\hline \multirow{3}{*}{30 days } & 1 & $9.74^{\mathrm{a}}$ & $3.35^{\mathrm{a}}$ & $2.75^{\mathrm{c}}$ & $15.84^{\mathrm{a}}$ \\
\hline & 2 & $7.38^{\mathrm{c}}$ & $1.08^{\mathrm{c}}$ & $4.30^{\mathrm{a}}$ & $12.76^{\mathrm{d}}$ \\
\hline & 3 & $8.01^{\mathrm{bc}}$ & $2.81^{\mathrm{b}}$ & $3.99^{b}$ & $14.82^{\mathrm{c}}$ \\
\hline
\end{tabular}

Mean values $(n=5)$ in each column followed by the same letters are not significantly different at $P \leq 0.05$ by Duncan's multiple range test. 
TABLE 4. Effect of irrigation with wastewater on total nitrogen, total protein, total soluble sugars, total carbohydrates, anthocyanine content, proline content, antioxidant enzymes (catalase, peroxidase and polyphenol oxidase) activities in Pisum sativum seedling. 1): Uncontaminated water as control (El-Mazalat station), 2): Industrial wastewater (Mostourd station), 3): Industrial wastewater (AbuZa'baal station).

\begin{tabular}{|c|c|c|c|c|c|c|c|c|c|c|}
\hline \multirow[b]{2}{*}{ Stage } & \multirow[b]{2}{*}{ 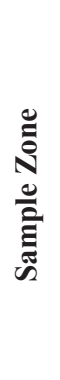 } & \multicolumn{4}{|c|}{ Metabolic Contents ( $\left.\mathrm{mg} \mathrm{g}^{-1} \mathrm{DW}\right)$} & \multirow[b]{2}{*}{ 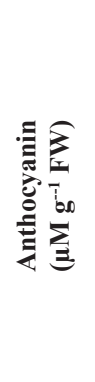 } & \multirow[b]{2}{*}{ 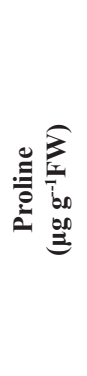 } & \multicolumn{3}{|c|}{$\begin{array}{c}\text { Enzymatic activities } \\
\left.\text { (Unit } \mathbf{g}^{-1} \mathbf{F W}\right)\end{array}$} \\
\hline & & 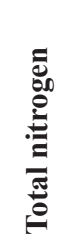 & 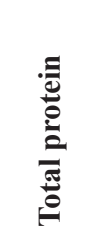 & 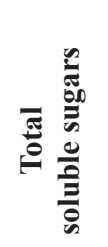 & 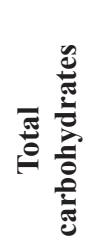 & & & Catalase & Peroxidase & $\begin{array}{l}\text { Polyphenol } \\
\text { oxidase }\end{array}$ \\
\hline \multirow{3}{*}{15 days } & 1 & $9.4^{\mathrm{a}}$ & $52.5^{\mathrm{a}}$ & $2.84^{\mathrm{d}}$ & $4.4^{\mathrm{d}}$ & $1.92^{\mathrm{c}}$ & $15.8^{\mathrm{f}}$ & $210^{\text {bcd }}$ & $25.4^{\mathrm{b}}$ & $15.9^{\mathrm{d}}$ \\
\hline & 2 & $6.8^{\mathrm{c}}$ & $42.5^{\mathrm{bcd}}$ & $3.95^{\mathrm{bcd}}$ & $10.5^{\mathrm{b}}$ & $3.83^{\mathrm{ab}}$ & $22.7^{\mathrm{d}}$ & $300^{\mathrm{a}}$ & $30.7^{\mathrm{a}}$ & $20.2^{\mathrm{b}}$ \\
\hline & 3 & $7.7^{\mathrm{bc}}$ & $47.4^{\mathrm{ab}}$ & $3.50^{\mathrm{cd}}$ & $6.1^{\mathrm{cd}}$ & $2.79^{\mathrm{bc}}$ & $19.6^{\mathrm{e}}$ & $255^{\mathrm{ab}}$ & $27.1^{\mathrm{b}}$ & $17.3^{\mathrm{cd}}$ \\
\hline \multirow{3}{*}{30 days } & 1 & $8.2^{b}$ & $45.0^{\mathrm{bc}}$ & $4.48^{\mathrm{bc}}$ & $6.5^{\mathrm{cd}}$ & $3.25^{\mathrm{bc}}$ & $49.2^{\mathrm{c}}$ & $165^{\mathrm{d}}$ & $22.9^{c}$ & $17.4^{\text {cd }}$ \\
\hline & 2 & $6.0^{c}$ & $37.5^{\mathrm{d}}$ & $6.92^{\mathrm{a}}$ & $13.6^{\mathrm{a}}$ & $4.67^{\mathrm{a}}$ & $75.1^{\mathrm{a}}$ & $225^{\mathrm{bc}}$ & $29.8^{\mathrm{a}}$ & $24.2^{\mathrm{a}}$ \\
\hline & 3 & $6.6^{\mathrm{c}}$ & $41.3^{\mathrm{cd}}$ & $5.15^{\mathrm{b}}$ & $8.5^{\mathrm{bc}}$ & $3.81^{\mathrm{ab}}$ & $68.1^{\mathrm{b}}$ & $181^{\mathrm{cd}}$ & $26.3^{\mathrm{b}}$ & $19.1^{\mathrm{bc}}$ \\
\hline
\end{tabular}

Mean values $(\mathrm{n}=5)$ in each column followed by the same letters are not significantly different at $\mathrm{P} \leq 0.05$ by Duncan's multiple range test.

The total content of soluble sugars and carbohydrates was significantly increased in plants irrigated with wastewater collected from the chosen stations as compared with those plants irrigated with water from control station at the experimental periods (15 and 30 days of germination) (Table 4). These results agreed with those of Naaz \& Pandey (2010) who showed that the irrigation with $50 \%$ wastewater to lettuce (Lactuca sativa L.) plant cause an enhanced increase in soluble sugar content.The increase in total carbohydrate content in the wastewater irrigated crops (Brassica oleracea and Spinacia oleracea) was also recorded by Bamniya et al. (2010). Noori \& Norzi (2014) found that water soluble carbohydrates were increased in wastewater treated Aegilops columnaris plants. The tolerance mechanism of wastewater stress may be associated with accumulation of osmoprotectants such as soluble sugars that protect cell from stress by balancing the osmotic strength, membrane stability (Patade et al., 2011). The present results indicated that the content of anthocyanine (Table 4) showed significant enhancement in the investigated plants irrigated with wastewater in all sites as compared with the control. Plants under stress accumulate a large number of metabolites such as anthocyanine as osmo-protectants that play a protective function in plants under stress (Abbas, 2013).These results are in line with those concluded by Sonnenberg et al., (2013) who found that the higher anthocyanin contents present in different cucumber organs could serve as defense compound against abiotic stresses such as water stress. This increase in anthocyanin levels may be due to the stimulation of anthocyanin hydroxylation by up regulating the anthocyanin gene encoding enzyme (Mattivi et al., 2006). In addition, its production can be as a result of increasing sugar accumulation that accelerates the generation of anthocyanin (Castellarin et al., 2007). As shown from the results, plants grown at waste water irrigated sites showed higher levels of proline than those irrigated with water of control station at chosen periods of germination (Table 4). These results agreed with the results of Anita \& Madhoolika (2010) who found that proline content was increased in Beta vulgaris L. plants irrigated with waste water in suburban stations than ground water irrigated ones. The increase in the levels of heavy metals in wastewater is known to affect permeability of cell membranes that may lead to the induction of the production of proline (Basak et al., 2001). Also, Noori \& Norzi (2014) demonstrated that proline content was induced in Aegilops columnaris plant that irrigated with wastewater.Al- 
Absi (2008) reported that proline content increases the stress tolerance of plants through mechanisms such as osmotic adjustment, stabilization of proteins and scavenging of ROS such as hydroxyl radicals. Verbruggen \& Hermans (2008) reported that the accumulation of heavy metals would lie in their contribution in the maintenance of water balance, and they concluded that the main effect of metals is the proline production that may be combined with the osmo - regulation, enzyme protection and metal sequestration. Consequently, proline production could be used as real indicator for stress tolerance. Antioxidant enzymes (catalase, peroxidase and polyphenol oxidase) also showed an enhanced increase in their activities in Pisum sativum seedlings irrigated with wastewater collected from selected sites as compared with those of the control (Table 4). Similar findings have been reported by Noori \& Norzi (2014) who concluded that catalase contents were increased in Aegilops columnaris plant that irrigated with waste water. In addition, catalase and peroxidase were increased in concentrations (up to $100 \%$ ) in wastewater-irrigated maize seedlings (Daud et al., 2016). Polyphenol oxidase is involved in the defense mechanism and its level is increased in plants against biotic and abiotic stresses (Dudjak et al., 2004). The Polyphenol oxidase activity (PPO) in Pisum grown under various waste stresses showed a progressive increase in plants irrigated with wastewater in all sites as compared with the control. The antioxidant enzymes play a significant role in defense system against oxidative stress and considered to be as indicators of metal toxicity (Singh \& Agrawal, 2007). If heavy metals have an excessive concentration above the permissible levels as established according to the FAO/WHO (1999) may sometimes increase it to the alarming limits that may cause human diseases (Mohamed et al., 2003). The analysis of the investigated plants irrigated with collected wastewater showed that concentrations of $\mathrm{Fe}$ and $\mathrm{Na}$ were higher than those in the control but they showed highly significant decrease in $\mathrm{Mg}$ and $\mathrm{K}$ in these plants. The present results showed that the heavy metals $\mathrm{Zn}, \mathrm{Cd}, \mathrm{Ni}$ and $\mathrm{Cu}$ were significantly increased in Pisum sativum plants irrigated with wastewater as compared with the corresponding controls, and this accumulation was more detected in the 30-days old plants (Table 5). This is probably due to the high levels of these elements in the wastewater. Al-Nakshabandi et al. (1997) reported the induction of the concentrations of $\mathrm{P}, \mathrm{N}, \mathrm{Ca}, \mathrm{Mg}, \mathrm{Na}$ and $\mathrm{K}$ in eggplants leaves and fruits irrigated with waste water. Shukry (2001 b) stated that Faba bean plants irrigated with industrial effluents showed an increase of $\mathrm{K}, \mathrm{Na}$ and $\mathrm{Ca}$. Tawfik (2008) showed that Faba bean plants irrigated with wastewater exhibited the highest levels of $\mathrm{N}, \mathrm{P}, \mathrm{K}, \mathrm{Ca}, \mathrm{Na}$ and $\mathrm{S}$. It was reported that the safe values for $\mathrm{Cu}, \mathrm{Pb}, \mathrm{Cd}, \mathrm{Ni}$ and $\mathrm{Zn}$ in fruit and vegetables recommended by the $\mathrm{WHO} /$ FAO are $40,0.3,0.2,4$ and $4.5 \mathrm{mg} / \mathrm{kg}$, respectively (Husain et al., 1995).

TABLE 5.The content of heavy metals and ion contents in Pisum sativum seedling irrigated with wastewater samples collected from chosen sites at experimental periods. 1): Uncontaminated water as control (ElMazalat station), 2): Industrial wastewater (Mostourd station) and 3): Industrial wastewater (AbuZa'baal station).

\begin{tabular}{|c|c|c|c|c|c|c|c|c|c|}
\hline \multirow{2}{*}{ Stage } & \multirow{2}{*}{$\begin{array}{c}\text { Sample } \\
\text { Zone }\end{array}$} & \multicolumn{4}{|c|}{ Heavy metals(mg g-1) } & \multicolumn{4}{|c|}{ Element ions $\left(\mathrm{mg} \mathrm{g}^{-1}\right)$} \\
\hline & & $\mathbf{Z n}^{+2}$ & $\mathbf{C d}^{+2}$ & $\mathbf{N i}^{+2}$ & $\mathrm{Cu}^{+2}$ & $\mathbf{M g}^{+2}$ & $\mathrm{Fe}^{+2}$ & $\mathbf{K}^{+}$ & $\mathbf{N a}^{+}$ \\
\hline \multirow{3}{*}{15 days } & 1 & $0.101^{\mathrm{d}}$ & $0.032^{\mathrm{c}}$ & $0.041^{\mathrm{d}}$ & $0.020^{\mathrm{b}}$ & $0.702^{\mathrm{ab}}$ & $0.108^{\mathrm{d}}$ & $23^{\mathrm{c}}$ & $4^{c}$ \\
\hline & 2 & $0.150^{\mathrm{bc}}$ & $0.061^{\mathrm{ab}}$ & $0.063^{\mathrm{bc}}$ & $0.028^{b}$ & $0.441^{\mathrm{c}}$ & $0.200^{\mathrm{cd}}$ & $14^{\mathrm{d}}$ & $8^{\mathrm{bc}}$ \\
\hline & 3 & $0.121^{\mathrm{d}}$ & $0.047^{\mathrm{bc}}$ & $0.052^{\mathrm{cd}}$ & $0.026^{\mathrm{b}}$ & $0.573^{\mathrm{bc}}$ & $0.330^{\mathrm{bc}}$ & $19^{\mathrm{cd}}$ & $5^{c}$ \\
\hline \multirow{3}{*}{30 days } & 1 & $0.123^{\mathrm{cd}}$ & $0.045^{\text {bc }}$ & $0.055^{\mathrm{c}}$ & $0.031^{\mathrm{b}}$ & $0.861^{\mathrm{a}}$ & $0.304^{\mathrm{bcd}}$ & $36^{\mathrm{a}}$ & $8^{\mathrm{bc}}$ \\
\hline & 2 & $0.185^{\mathrm{a}}$ & $0.077^{\mathrm{a}}$ & $0.081^{\mathrm{a}}$ & $0.067^{\mathrm{a}}$ & $0.605^{\mathrm{bc}}$ & $0.421^{\mathrm{b}}$ & $22^{\mathrm{c}}$ & $17^{\mathrm{a}}$ \\
\hline & 3 & $0.158^{\mathrm{ab}}$ & $0.051^{\mathrm{a}}$ & $0.062^{\mathrm{ab}}$ & $0.044^{\mathrm{ab}}$ & $0.731^{\mathrm{ab}}$ & $0.690^{\mathrm{a}}$ & $30^{\mathrm{b}}$ & $11^{\mathrm{b}}$ \\
\hline
\end{tabular}

Mean values $(\mathrm{n}=5)$ in each column followed by the same letters are not significantly different at $\mathrm{P} \leq 0.05$ by Duncan's multiple range test. 
The electrophoretic banding patterns of proteins extracted from Pisum sativum var Master $\mathrm{B}$ seedlings irrigated with industrial wastewater showed a marked variations in proteins profile. The disappearance of certain bands and appearance of new bands/ or increase or decrease in the intensity of other protein bands were reported (Fig. 2 and Table 6). Bands with different molecular weights (MW) were detected and ranging from $7.8 \mathrm{kDa}$ to $321 \mathrm{kDa}$ and the total number of bands among samples ranging from 14 in control to 13 in the two other samples. The industrial polluted Pisum seedlings were characterized by the presence of 8 common protein bands and their MW are; 276.9, 258.4, 213.8, 117.4, 42.6, 28.5 and $7.8 \mathrm{kDa}$. Also, there are 5 common bands specific to the 15 days old seedlings and their MW are; 321.0, 246.3, $192.5,95.4$ and $13.2 \mathrm{kDa}$. There are also 3 common bands specific to the 30 days old seedlings and their MW are ; 313.1, 241.2 and 180.2 $\mathrm{kDa}$. On the other hand, the results revealed that, samples from each station are characterized by the presence of one or more specific bands. The first sample (irrigated from El-Mazalat station) was characterized by one band with MW201.1 kDa in the 15 day old seedlings and 2 bands with MW120.2 and $17.8 \mathrm{kDa}$ in the 30 day old seedlings. The second sample (irrigated from Mostourd station) has a specific 3 bands with MW 228.9, 185.7 and $67.9 \mathrm{kDa}$ in the15 days old seedlings and 3 bands with MW228.9, 89.6 and $81.2 \mathrm{kDa}$ in the 30 days old seedlings. The third samples (irrigated from Abu Za'baal station) have a specific one band with MW $33.9 \mathrm{kDa}$ in the 15 days old seedlings and 2 bands with MW 94.0 and $60.1 \mathrm{kDa}$. In addition, the above results showed that, samples from each station were characterized by specific bands related to the nature of industrial pollutant in it. The highest number of bands is 16 and 15 bands which were recorded in the 15 and 30 days old Pisum seedlings respectively irrigated with water collected from Mostourd station. It was known that plants respond to heavy metals stress by the synthesis of phytoclelatins, peptide and related proteins (Didierjean et al., 1996). These proteins might have helped for encountering the heavy metal inhibitory effects. Moreover, excess heavy metals lead to generate oxidative stress due to an increase in the levels of reactive oxygen species (ROS) which affect mainly amino acids, protein and nucleic acids (Brahim \& Mohamed, 2011). On the other hand,the appearance or disappearance of new protein bands was attributed to the alternation in the gene structure or gene regulation due to the mutagenic effect of heavy metals present in wastwater and these mutational effects occurring in the regulatory genes may lead to decrease or constative expression of concerned genes that will result in the disappearance of some proteins or change in their intensities (Zeid \& Abou-El Ghate, 2007). Similar result was obtained by Daud et al. (2016)

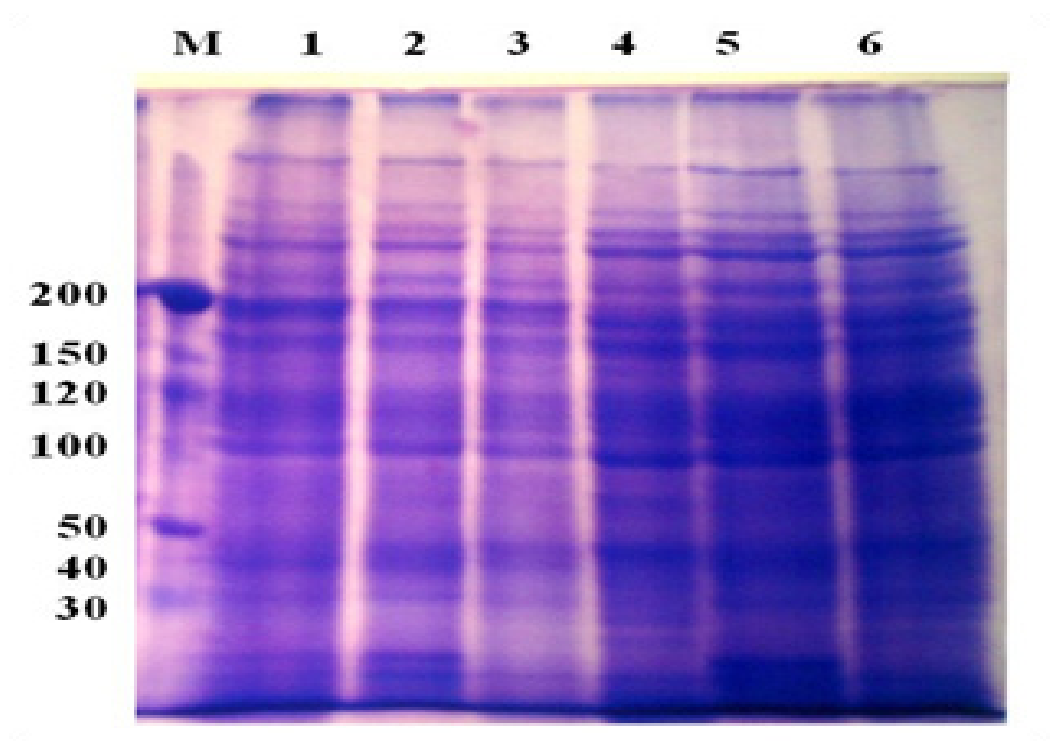

Fig. 2. Electrophoretic banding profile of protein extracted from the leaves of Pisum sativum seedlings irrigated with wastewater. M, Marker protein; Lane 1,4: Uncontaminated water (control) (El-Mazalat station) for 15 and 30 days old seedlings, respectively, Lane 2,5: Industrial wastewater (Mostourd station) for 15 and 30 days old seedlings, respectively, Lane 3,6: Industrial wastewater (Abu- Za'baal station) for 15 and 30 days old seedlings, respectively.

Egypt. J.Bot. 57, No.3 (2017) 
TABLE 6. Protein electrophoretic pattern of Pisum sativum seedlings irrigated with waste water.(1,4: Uncontaminated water (control) for 15 and 30 days old seedlings, respectively; 2,5: Industrial wastewater (Mostourd station) for 15 and 30 days old seedlings, respectively; 3,6: Industrial wastewater (Abu- Za'baal station) for 15 and 30 days old seedlings, respectively.

\begin{tabular}{|c|c|c|c|c|c|c|c|}
\hline \multicolumn{2}{|c|}{ Stages } & \multicolumn{3}{|c|}{15 days } & \multicolumn{3}{|c|}{30 days } \\
\hline $\begin{array}{l}\text { No. of } \\
\text { Bands }\end{array}$ & M. wt kDa. & 1 & 2 & 3 & 4 & 5 & 6 \\
\hline 1 & 321.0 & + & + & + & & & \\
\hline 2 & 313.1 & & & & + & + & + \\
\hline 3 & 276.9 & + & + & + & + & + & + \\
\hline 4 & 258.4 & + & + & + & + & + & + \\
\hline 5 & 246.3 & + & + & + & & & \\
\hline 6 & 241.2 & & & & + & + & + \\
\hline 7 & 228.9 & & + & & & + & \\
\hline 8 & 213.8 & + & + & + & + & + & + \\
\hline 9 & 201.1 & + & & & & & \\
\hline 10 & 192.5 & + & + & + & + & + & \\
\hline 11 & 185.7 & & + & & & & \\
\hline 12 & 180.2 & & & & + & + & + \\
\hline 13 & 160.0 & + & + & + & + & + & + \\
\hline 14 & 133.9 & & & + & & & \\
\hline 15 & 120.2 & & & & + & & \\
\hline 16 & 117.4 & + & + & + & + & + & + \\
\hline 17 & 95.4 & + & + & + & & & \\
\hline 18 & 94.0 & & & & & & + \\
\hline 19 & 89.6 & & & & & + & \\
\hline 20 & 81.2 & & & & & + & \\
\hline 21 & 67.9 & & + & & & & \\
\hline 22 & 60.1 & & & & & & + \\
\hline 23 & 42.6 & + & + & + & + & + & + \\
\hline 24 & 28.5 & + & + & + & + & + & + \\
\hline 25 & 17.8 & & & & + & & \\
\hline 26 & 13.2 & + & + & + & & & \\
\hline 27 & 7.8 & + & + & + & + & + & + \\
\hline Total of bands & & 14 & 16 & 14 & 14 & 15 & 13 \\
\hline
\end{tabular}




\section{Conclusion}

The present study concludes that based on the measured growth parameters the $3^{\text {rd }}$ more treated industrial wastewater of Abu Za'baal station could successfully be used for irrigation of plants. This is because it contains reduced amounts of heavy metals as compared with water collected from the second station. Also, the concentration of mineral ions in Pisum sativum seedlings was generally more than those in seedlings irrigated with water collected from the second station which indicates different mechanisms of alleviating the wastewater stress.

\section{References}

Abbas, S.M. (2013) Low levels of selenium application attenuate low temperature stress in sorghum [Sorghum bicolor L. Moench] seedlings. Pakistan Journal of Botany, 45(5), 1597-1604.

Aebi, H. (1984) Catalase in vitro. Methods Enzymology, 105, 121-126

Al-Absi, K.M. (2008) Effect of irrigation with treated industrial effluent on growth and biochemical constituents of olives. Bulgarian Journal of Agricultural Science, 14(6), 564-575.

Allen, J.P., Feher, G., Yeates, T.O., Rees, D.C., Deisenhofe, J., Michel, H. and Huber, R. (1986) Structural homology of reaction centers from Rhodopseudomonas sphaeroides and Rhodopseudomona viridis as determined by X- ray diffraction. Proceedings of the National Academy of Sciences, U.S.A. 83, pp. 8589-8593.

Al-Nakshabandi, G.A., Saqqar, M.M., Shatanawi, M.R., Fayyad, M. and Al-Horani, H. (1997) Some environmental problems associated with the use of treated wastewater for irrigation in Jordan. Agricultural Water Management, 34, 81-94.

Anita, S. and Madhoolika, A. (2010) Effect of municipal wastewater irrigation on availability of heavy metals and morpho-physiological characteristics of Beta vulgaris L. Journal of Environmental Biology, 31(5), 727-736.

APHA (2005) "Standard Methods for the Examination of Water and Wastewater" $21^{\text {st }} \mathrm{ed}$. American Public Health Association, Washington, D.C.

Asgharipour, M.R., Khatamipour, M. and RazaviOmrani, M. (2011) Phytotoxicity of cadmium on seed germination, early growth, proline and carbohydrate content in two wheat verities. Advances in Environmental Biology, 5(4), 559-565.
Bamniya, B.R., Vidhya, K. and Kapoor, C.S. (2010) Physiological and biochemical studies on the effect of wastewater on selected crop plants. Biological Forum - An International Journal, 2 (2), 1-3.

Basak, M., Sharma, M. and Chakraborty, U. (2001) Biochemical responces of Camellia sinesis L. O. Kuntze to heavy metal stress. Journal of Environmental Biology, 22, 37- 41.

Bates, L.S., Waldren, R.P. and Teare, I.D. (1973) Rapid determination of free proline for water stress studies. Plant and Soil, 39, 205-207.

Bini, C., Wahsha, M., Fontana, S. and Maleci, L. (2012) Effects of heavy metals on morphological characteristics of Taraxacum officinale Web growing on mine soils in NE Italy. National Geographic Explorer, 123, 101-108.

Brahim, L. and Mohamed, M. (2011) Effect of copper stress on antioxidative enzymes, chlorophyll and protein content in Atriplex halimus. African Journal of Biotechnology, 10, 10143-10148.

Briccoli, B.C., Basta, P., Tocci, C. and Turco, D. (1994) Influence of irrigation with brakish water on young olive plants. Olivae, 53, 35-38.

Castellarin, S.D., Pfeiffer, A., Sivilotti, P., Degan, M., Peterlunger, E. and Di Gaspero, G. (2007) Transcriptional regulation of anthocyanin biosynthesis in ripening and induce changes in gene expression regulating flavonoid biosynthesis in grape berries. Planta, 227, 101-112.

Chapman, H.D. and Pratt, P.F. (1978) "Methods of Analysis for Soils, Plants and Waters", Division of Agricultural Sciences, University of California, Berkely, USA, 30 - 43.

Daud, M.K., Hassan, S., Azizullah, A., Jamil, M., Rehan, N., Irum, R., Qaiser, M.K. and Zhu, S.J. (2016) Physiological, biochemical and genotoxic effects of wastewater on maize seedlings. Polish Journal of Environmental Studies, 25(2), 563-571.

Didierjean, L., Frendo, P., Nasser, W., Genot, G., Marivet, J. and Burkad, G. (1996) Heavy metals responsive genes in maize: identification and comparison of their expression upon various form of biotic stress. Planta, 199, 1-8.

Dubois, M., Gilles, K.A., Hamilton, J.K, Roberts, P.A. and Smith, F. (1956) Calorimetric method for determination of sugars and related substances. Analytical Biochemistry, 28, 350-356.

Dudjak, J., Lachman, J., Miholova, D., Kolihova, D. and 
Pivec, V. (2004) Effect of cadmium on polyphenol content in young barley plants (Hordeum vulgare L.). Plant, Soil and Environment, 50, 471-477.

El-Sayed, S.A. (2008) Microbiological studies on Ismailia Canal, River Nile, Egypt. M. Sci. Thesis, Faculty of Science Al-Azhar University.

El-Sharabasy, H.M. and Ibrahim, A. (2010) Heavy metal accumulation in oribatid mite species (Acari: Oribatida) in agroecosystems in Egypt. A case study. Munis Entomology\& Zoology, 5, 1182-1188.

FAO/WHO(1999) Expert Committee on Food Additives, Summary and conclusions, in: Proceedings of the $53^{\text {rd }}$ Meeting Joint FAO/WHO Expert Committee on Food Additives, Rome, Italy.

Gratäo, L.P., Polle, A., Lea, P.J. and Azevedo, R.A. (2005) Making the life of heavy metal stressed plants a little easier. Functional Plant Biology, 32, 481494.

Gruszecki, W.I. and Strzatka, K. (1991) Does the xanthophylls cycle take part in the regulation of fluidity of the thylakoid membrane? Biochimica et Biophysica Acta, 1060, 310-314.

Hassanein, R.A., Hashem, A.H., El-Deep, H.M. and Shouman, A. (2013) Soil contamination with heavy metals and its effect on growth, yield and physiological responses of vegetable crop plants (Turnip and Lettuce). Journal of Stress Physiology and Biochemistry, 9 (4), 145-162.

Hong, Z., Lakkineni, K., Zhang, Z. and Verma, D.P. (2000) Removal of feedback inhibition of 1- Pyrroline-5-Carboxylate synthetase results in increased proline accumulation and protection of plants from osmotic stress. Plant Physiology, 122, 36-1129.

Hsu, Y.T. and Kao, C.H. (2003) Role of abscisic acid in cadmium tolerance of rice (Oryza sativa L.) seedlings. Plant, Cell and Environment, 26, 867-874.

Husain, A., Baroon, Z., Al-khalafawi, M., Al-Ati, T. and Sawaya, W. (1995) Toxic metals in imported fruits and vegetables marketed in Kuwait. Environment International, 21(6), 803-805.

ISTA (1993) International rules for seed testing. International Seed Testing Association. Seed Science \& Technology, 21, Supplement 25-30 and 141-186.

Kar, M. and Mishra, D. (1976) Catalase, peroxidase, and polyphenoloxidase activities during rice leaf senescence. Plant Physiology, 57, 315- 319.
Khalil, M.K.H., Radwan, A.M. and El-Moselhy, K.H.M. (2007) Distribution of phosphorus fractions and some of heavy metals in surface sediments of Burullus lagoon and adjacent Mediterranean Sea. Egypt. Egyptian Journal of Aquatic Research, 33 (1), 277-289.

Krizek, D.T., Kramer, G.F., Upadhyaya, A. and Mirecki, R.M. (1993) UV-B Response of cucumber seedling grown under metal halid and high pressure sodium/ deluxe lamps. Physiology of Plant, 88, 350-358.

Laemmli, U.K. (1970) Cleavage of structural proteins during the assembly of the head of bacteriophage T4 Nature, 227(5259), 680-685.

Lichtenthaler, H.K. and Wellburn, A.R. (1983) Determinations of total carotenoids and chlorophylls $\mathrm{a}$ and $\mathrm{b}$ of leaf extracts in different solvents. Biochemical Society Transactions, 11, 591 - 592.

Long, X.X., Yang, X.E., Ni, W.Z., Ye, Z.Q., He, Z.L., Calvert, D.V. and Stoffella, J.P. (2003) Assessing zinc thresholds for phytotoxicity and potential dietary toxicity in selected vegetable crops. Communications in Soil Science and Plant Analysis, 34, 1421-1434.

Lowry, O.H., Rosembrough, N.J., Farr, A.L., Randall, R.J. (1951) Protein measurement with the Folin phenol reagent. Journal of Biological Chemistry, 193(1), 267-275.

Majid, N.M., Islam, M.M. and Riasmi, Y. (2012) Heavy metal uptake and translocation by Jatropha curcas L. in sawdust sludge contaminated soils. Australian Journal of Crop Science, 6, 891-898.

Mattivi, F., Guzzon, R., Vrhovsek, U., Stefanini, M. and Velasco, R. (2006) Metabolite profiling of grape: flavonols and anthocyanins. Journal of Agricultural and Food Chemistry, 54, 7692-7702.

Metzner, H., Rau, H. and Senger, H. (1965) Untersuchungen Zur Synchronisier barkeep einZelner pigment.Mango I Mutanten Von chlorella. Planta, 65, 186.

Mohamed, A.E., Rashed, M.N. and Mofty, A. (2003) Assessment of essential and toxic elements in some kinds of vegetables. Ecotoxicology and Environmental Safety, 55(3), 251-260.

Naaz, S. and Pandey, S.N. (2010) Effects of industrial waste water on heavy metal accumulation, growth and biochemical responses of Lettuce (Lactuca sativa L.). Journal of Environmental Biology, 31, 273-276. 
Noori, M.M. and Norzi, R.M. (2014) Effects of municipal waste water irrigation on physiological and phytochemical parameters of Aegilops columnaris Zhuk. International Journal of Research in Agriculture and Food Sciences, 1(4), 1-9.

Pandey, S. and Srivastava, V.S. (2002) Heavy metal accumulation in industrial solid waste amended soils. Nature Environment and Pollution Technology, 1, 73-75.

Pandey, S.N. (2008) Growth and biochemical changes in pluse seedlings irrigated with effluent from electroplanting industry. Journal of Applied Biosciences, 34, 79-82.

Pantea, E., Romocea, T., Ghergheles, C. and Carbunaru, M. (2012) The impact of wastewater from treatment plant of Oradea on germination of Lycopersicon esculentum. University Oradea, Faculty of Environment and Protection, XIX, 769-776

Patade, V.Y., Maya, K. and Zakwan, A. (2011) Seed priming mediated germination improvement and tolerance to subsequent exposure to cold and salt stress in capsicum. Research Journal of Seed Science, 4 (3), 125-136.

RongGuo, T., Guo Ping, Z. and Yan Hue, Z. (2007) Physiological changes in barley plants under combined toxicity of aluminum, copper and cadmium. Colloids and Surfaces. B. Biointerfaces, $\mathbf{5 7}, 182-188$

Shukry, W.M. (2001a) Effect of industrial effluents polluting the River Nile on growth, metabolism and productivity of Triticum aestivum and Vicia faba plants. Pakistan Journal of Biological Sciences, 4(9), 1153-1159.

Shukry, W.M. (2001b) The effect of industrial effluents and vesicular-arbuscular mycorrhizae on nutrient distribution and concentration of wheat and bean plants. Journal of Biological Sciences, 1(8), 689-693.

Singh, R.P. and Agrawal, M. (2007) Effects of sewage sludge amendment on heavy metal accumulation and consequent responses of Beta vulgaris plants. Chemosphere, 67, 2229-2240.

Sonnenberg, D., Ndakidem, P.A. and Laubscher, C, (2013) The effects of various drip fertigated water quantities on flavonoid and anthocyanin content on hydroponically cultivated Cucumis sativa L. International Journal of Physical Sciences, 8 (19), 1012-1016.

Tawfik, K.M. (2008) A monitory field study at El-SaafHelwan Faba bean farms irrigated by industrial wastewater and polluted water with sewage. Journal of Applied Sciences Research, 4 (5), 492-499.

Toze, S. (2006) Reusse of effluent water benefits and risks. Agricultural Water Management, 80, 147-159.

Verbruggen N., Hermans C. (2008) Proline accumulation in plants: a review. Amino Acids. 35, 753-759.

Verma, S. and Dubey, R.S. (2001) Effect of cadmium on soluble sugars and enzymes of their metabolism in rice. Biologia Plantarum, 44, 117-123.

Yemm, E.W. and Willis, A.J. (1956) The respiration of barley plants. IX. The metabolism of roots during the assimilation of nitrogen. New Physiologist, 55 (2), 229-252.

Zeid, I.M. and Abou El Ghate, N.D. (2007) Effect of sewage water on growth, metabolism and yield of bean. Journal of Bio-Science, 7, 34-40.

(Received $31 / 5$ / 2017 ; acecpted $13 / 9$ / 2017 )

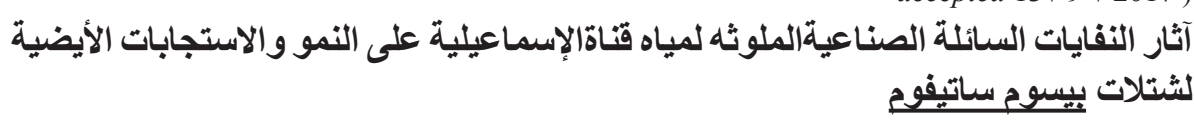

$$
\text { قبم العلوم البيولوجيا محمد أحمد و رانيا سامى حنفى }
$$

الهدف من هذا العمل تقييم تأثير مصادر تلوث المياه على قناة الإسماعيلية والنباتات المروية منها. تنتج المصادر الصناعية

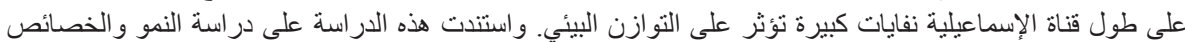

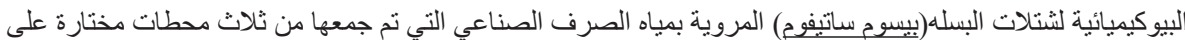

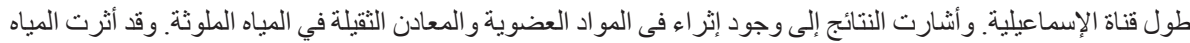

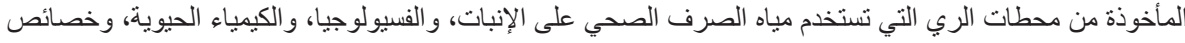

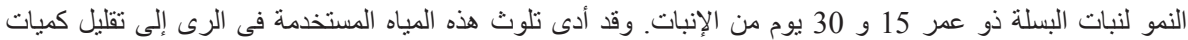

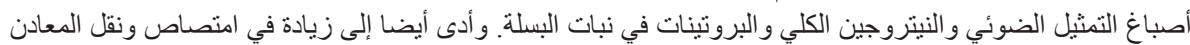

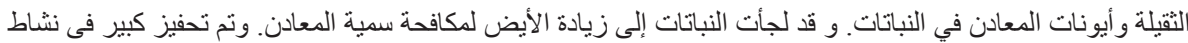

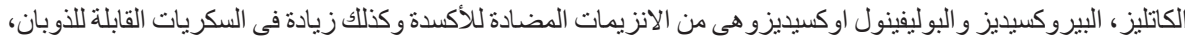

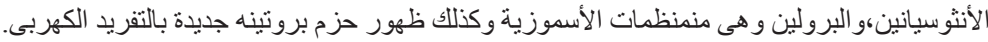

Egypt. J.Bot. 57, No.3 (2017) 